\title{
EFEKTIVITAS PENYULUHAN PENCEGAHAN THALASSEMIA DI SMPN 1 DAN SMPN 2 TEMPURAN KABUPATEN KARAWANG
}

\author{
Nur Suryawan ${ }^{1,2}$, Lulu Eva Rakhmilla ${ }^{1,2}$, Sarah Aurelia Saragih ${ }^{1,3}$, Firgie Fahira Amalia ${ }^{1,4}$, Dwita Fitricia ${ }^{1,5}$, \\ Oktavia Nur Azizah Jain ${ }^{1,6}$, Hialina Dinda Halimah ${ }^{1,7}$, Fikri Tsakif Faruqi ${ }^{1,8}$, \\ dan Mochammad Agung Seno Pambudi ${ }^{1,9}$ \\ Universitas Padjadjaran ${ }^{1}$, Fakultas Kedokteran ${ }^{2}$, Fakultas Psikologi ${ }^{3}$, Fakultas Kedokteran Gigi ${ }^{4}$, Fakultas Ilmu \\ Komunikasi ${ }^{5}$, Fakultas Keperawatan ${ }^{6}$, Fakultas Ilmu Sosial dan Ilmu Politik ${ }^{7}$, Fakultas Pertanian ${ }^{8}$, \\ Fakultas Perikanan dan Ilmu Kelautan ${ }^{9}$ \\ E-mail: nursuryawan@gmail.com
}

\begin{abstract}
ASBTRAK. Program untuk pendidikan, penyaringan, dan konseling siswa sekolah menengah pertama pada populasi berisiko tinggi penyakit thalassemia belum termasuk ke dalam program nasional. Minimnya informasi tentang penyakit thalassemia terutama pada populasi usia reproduktif menjadi kajian penting pada penelitian ini. Penelitian ini bertujuan untuk mengetahui adanya peningkatan pengetahuan mengenai thalassemia setelah diberikan edukasi kepada siswa Sekolah Menengah Pertama (SMP). Penelitian merupakan analitik kuantitatif dengan pre-test dan post-test dengan populasi siswa SMP di Kecamatan Tempuran, Kabupaten Karawang. Instrumen menggunakan kuesioner yang telah tervalidasi dan dianalisis dengan menggunakan uji t. Data diambil selama pelaksanaan penelitian terpadu KKN dengan memberikan kuesioner dua kali pengambilan, yaitu dalam pre-test dan post-test diselingi dengan edukasi informasi tentang thalassemia. Data yang dianalisis adalah jenis kelamin, usia, dan perubahan pengetahuan subjek. Dari 222 siswa yang memenuhi kriteria inklusi dari SMPN 1 dan SMPN 2 di Kecamatan Tempuran, 27 orang dikeluarkan dari penelitian karena mereka tidak ikut dalam salah satu test. Responden hasil pre-test baik SMPN 1 dan SMPN 2 memperoleh nilai minimum dan maksimum berturut-turut 4 dan 6. Kemudian setelah intervensi maka post test dilakukan, dengan hasil post-test yang signifikan dengan peningkatan rata-rata $1.09(\mathrm{t}=-$ 3,861; $\mathrm{p}<0,001)$ untuk SMPN 2 dan tidak ada peningkatan pengetahuan untuk subjek di SMP $1(\mathrm{t}=0,913 ; \mathrm{p}=0,364)$;. Pendidikan publik lebih lanjut dan konseling genetik yang tersebar luas sebelum pengujian sangat penting untuk keberhasilan program. Skrining individual saat masuk ke sekolah menengah pertama sebelum komitmen apapun mungkin lebih baik daripada skrining segera pra-nikah pada pasangan untuk mencegah peningkatan insidensi thalassemia di Indonesia.
\end{abstract}

Kata kunci: thalassemia; edukasi; murid SMP

ABSTRACT. Programs for education, screening, and counseling of junior high school students, in populations at high risk for beta thalassemia diseases, haven't existed an integrated program with national coverage. The lack of information about thalassemia, especially in the reproductive age population, is an important issue in this study. This study aims to evaluate the increase in knowledge about thalassemia after educational intervention. A cross-sectional study performed in two Junior High School students in Tempuran District, Karawang during the implementation of KKN integrated research by giving questionnaires twice taking, namely in the pre-test and post-test interspersed with the education of information on thalassemia. Data analyzed were gender, age, and changes in subject knowledge. We applied numerical comparative analytical study in pairs and paired t tests. Out of 222 students who fulfilled the inclusion criteria from SMP 1 and SMP 2 in Tempuran District, 27 people met the exclution criteria because they did not take part in one of the pre-test and post-test interventions. In the pre-test respondents both SMPN 1 and SMPN 2 obtained minimum and maximum values in a row 4 and 6. Then after the intervention was carried out then a post test was performed, which resulted in a significant result in the post test score there was an average increase of 1.09 ( $t=-3,861 ; p<0,001)$ for SMPN 2. Further public education and wide spread genetic counseling prior to testing is essential for the success of the program. Screening singles on admission to junior high school prior to any commitment may be preferable than screening immediately before the marriage certificate is issued to prevent an increased incidence of thalassemia in Indonesia.

Key words: thalassemia; education; students

\section{PENDAHULUAN}

Thalassemia berasal dari bahasa Yunani yang berarti laut, karena awal ditemukan kelainan tersebut di wilayah pesisir Laut Tengah. Karena adanya migrasi penduduk dan perkawinan campuran antara berbagai kelompok etnis maka penyebaran thalassemia saat ini telah mencapai negara di Eropa, Timur Tengah, Afrika dan Amerika Selatan. Hal ini menyebabkan thalassemia menjadi masalah kesehatan umum di dunia. Menurut data WHO yang diperoleh tahun 2008 diketahui bahwa setiap tahunnya lebih dari 9 juta wanita hamil pembawa sifat dengan resiko kemungkinan pasangan mereka juga adalah pembawa sifat, berkisar antara $0.1-40 \%$ (Modell and Darlison 2008). Setiap tahunnya kemungkinan bayi mengalami kelainan hemoglobin mencapai 332.000 dengan prevalensi 275.000 mengalami sickle cell anemia dan 56.000 mengalami thalassemia mayor (Modell and Darlison 2008).

Di seluruh dunia, 15 juta orang memiliki presentasi klinis dari thalassemia. Fakta ini mendukung thalassemia sebagai salah satu penyakit turunan yang terbanyak; menyerang hampir semua golongan etnik dan terdapat pada hampir seluruh negara di dunia (Pour, Hagh et al. 2015). Pada penelitian demografi dan prevalensi hemogl obinopati diperoleh data bahwa thalassemia menjadi 
masalah kesehatan yang signifikan pada $71 \%$ dari 229 negara di dunia. Di Indonesia, menurut data penelitian, proporsi penderita thalassemia terbesar di RSUP $\mathrm{H}$. Adam Malik Medan tahun 2006-2008 adalah suku Jawa dan Sunda (59.2\%), suku Aceh (18.3\%), Melayu (7.5\%), Batak (5\%), Minang (4.2\%), dan Cina (1.7\%) (Dewi 2009). Pada tahun 2017 frekuensi penyadang thalassemia bergantung transfusi sebanyak 43,75\%, merupakan prevalensi tertinggi di Indonesia. (YTI, 2017)

Kekhawatiran para pemerhati thalassemia di dunia terhadap tingginya angka kejadian thalassemia di dunia mendorong terbentuknya program pencegahan thalassemia. Program pencegahan thalassemia dapat memotong rantai pewarisan thalassemia dengan menekan perkawinan sesama pembawa sifat, hal ini terbukti secara signifikan mampu menurunan angka kelahiran penyandang thalassemia baru di banyak negara (Cousens, Gaff et al. 2010). Program pencegahan thalassemia bertujuan menurunkan angka kelahiran baru secara konsisten, hal ini merupakan bagian dari strategi pengendalian thalassemia. Penelitian awal mengenai pencegahan thalassemia pertama kali mulai diterapkan pada akhir tahun 1970an untuk populasi berisiko di negara-negara Mediterania (Cao and Kan 2013). Saat ini program pencegahan nasional yang komprehensif telah diterapkan di beberapa negara yang terdiri dari edukasi, skrining pembawa sifat, diagnosis pranatal dan praimplantasi, serta konseling genetik. Edukasi bertujuan untuk meningkatkan pemahaman tentang thalassemia dan meningkatkan kesadaran masyarakat untuk pentingnya melakukan skrining (Cousens, Gaff et al. 2010). Sebuah studi menyebutkan program pencegahan yang sukses di negara-negara Mediterania adalah melalui program edukasi yang intensif terhadap pegawai kesehatan dan masyarakat umum. Suatu studi mengkaji mengenai metode edukasi yang efektif untuk menyampaikan poin penting dalam menilai pengetahuan masyarakat tentang thalassemia memberikan hasil edukasi dengan media video terbukti efektif meningkatkan pengetahuan tentang thalassemia (Rakhmilla, Larasati et al. 2018). Edukasi publik penting untuk menghapus stigmatisasi di masyarakat tentang thalassemia dan menjaring pembawa sifat untuk melakukan autoscreening (Cousens, Gaff et al. 2010). Usia reproduktif remaja awal adalah usia 12-18 tahun yang memungkinkan seseorang akan menikah dan mempunyai keturunan. Usia ini menunjukkan bahwa pengetahuan tentang thalassemia sangat penting untuk diberikan kepada remaja setingkat siswa Sekolah Menengah Pertama (SMP) yang berpeluang tinggi untuk menikah setelah menyelesaikan pendidikannya sehingga perlu adanya konseling dini sebelum menikah.

\section{METODE}

Metode yang digunakan pada penelitian ini adalah studi eksperimental semu (quasi experimental) dengan menggunakan pendekatan analitik kuantitatif dengan pre test dan post test yang merupakan bagian dari kegiatan pencegahan thalassemia dilakukan oleh Pusat Studi Genetika Medis Fakultas Kedokteran Universitas Padjadjaran Bandung. Subjek penelitian adalah siswa/ siswi SMP Negeri 1 dan 2 Tempuran, Kecamatan Tempuran, Kabupaten Karawang, Provinsi Jawa Barat. Kriteria inklusi adalah bersedia mengikuti kegiatan edukasi, dan mengisi kuesioner pre dan post-test dengan lengkap. Sedangkan kriteria ekslusi adalah siswa/siswi yang telah mendapatkan informasi tentang thalassemia. Hasil yang dinilai adalah pengetahuan sebelum dilakukan intervensi dan setelah dilakukan intervensi. Total sampel yang memenuhi kriteria inklusi dan ekslusi sebanyak 195 orang.

Instrumen yang digunakan pada penelitian ini adalah kuesioner yang telah tervalidasi, terdiri dari 20 pernyataan benar dan salah mengenai pengetahuan thalassemia. Proses pengambilan data pada penelitian ini dilakukan sebanyak dua kali di waktu yang sama. Responden yang telah terpilih akan diberikan lembar kuesioner dimana pengisian kuesioner dilakukan sebanyak dua kali. Pengisian kuesioner pertama dianggap sebagai pre test, kemudian dilanjutkan dengan pemberian materi pengetahuan tentang thalassemia dengan durasi selama 15 - 20 menit. Langkah berikutnya dilanjutkan dengan pengisian kuesioner kedua dianggap sebagai post test yang dilakukan setelah intervensi. Perlakukan intervensi menggunakan proyektor dan layar putih serta memperhatikan kondisi ruangan yang nyaman sehingga responden dapat lebih fokus memperhatikan layar saat pemaparan materi.

Analisis data yang dilakukan adalah analisis deskriptif untuk menggambarkan karakteristik populasi meliputi perhitungan rata-rata, standar deviasi dan persentase. Tingkat pengetahuan dibagi menjadi pengetahuan baik (skor 16-20), pengetahuan sedang (skor 9-15), dan pengetahuan kurang (skor < 8), Gambaran hasil skrining dilakukan dengan analisis proporsi. Perbandingan nilai hematologis antara tersangka pembawa sifat dengan normal dilakukan dengan analisis paired t test.

\section{HASIL DAN PEMBAHASAN}

Hasil dari pengambilan responden didapatkan sebanyak 222 siswa yang memenuhi kriteria inklusi dan eksklusi baik dari SMPN 1 Tempuran dan SMPN 2 Tempuran. Dari 222 subjek tersebut sebanyak 27 orang memenuhi kriteria drop out karena tidak mengikuti kegiatan salah satu intervensi baik pre-test maupun post test. Seluruh subjek yang dropout berasal dari SMPN 1. Sehingga total subjek penelitian yang didapatkan adalah 195 orang dan diperoleh data sebagai berikut

Data pada tabel 1 menunjukkan karakteristik dari subjek penelitian. Pada data tersebut diperoleh bahwa distribusi usia yang sama pada kedua sekolah yang diteliti dan lebih dari setengah subjek penelitian berjenis kelamin wanita. Sebagian besar populasi 
Tabel 1. Karakteristik responden

\begin{tabular}{lll}
\hline Variabel & $\begin{array}{l}\text { SMPN 1 } \\
(\mathrm{n}=93)\end{array}$ & SMPN 2 (n=102) \\
\hline $\begin{array}{l}\text { Usia (rata-rata, } \\
\text { simpangan baku) }\end{array}$ & $12,49 \pm 0,701$ & $12,24 \pm 0,583$ \\
$\begin{array}{l}\text { Jenis Kelamin, n }(\%) \\
\quad \text { Laki-laki }\end{array}$ & $42(45,2)$ & $44(43,1)$ \\
$\quad$ Wanita & $51(54,8)$ & $58(56,9)$ \\
$\begin{array}{l}\text { Pendapatan keluarga } \\
\text { per bulan }\end{array}$ & & \\
$<2,6$ juta & $79(85)$ & $82(80,39)$ \\
$2,6-5,2$ juta & $7(7,5)$ & $3(2,94)$ \\
$5,2-7,8$ juta & $7(7,5)$ & $18(16,67)$ \\
\hline
\end{tabular}

memiliki status ekonomi yang rendah, yang diukur dari pendapatan keluarga setiap bulan. Intervensi edukasi yang diberikan, dalam hal ini adalah pemberian penyuluhan memperlihatkan adanya perubahan. Perubahan tingkat pengetahuan tentang thalassemia sebelum dan sesudah dilakukan intervensi pada seluruh responden memiliki kecenderungan pola yang sama (Gambar 1), namun bila dibagi berdasarkan lokasi SMP, terlihat bahwa siswa/siswi SMP 2 Tempuran mengalami perubahan pengetahuan menjadi lebih baik dibandingkan dengan SMP 1 yang tidak mengalami perubahan (Gambar 2).

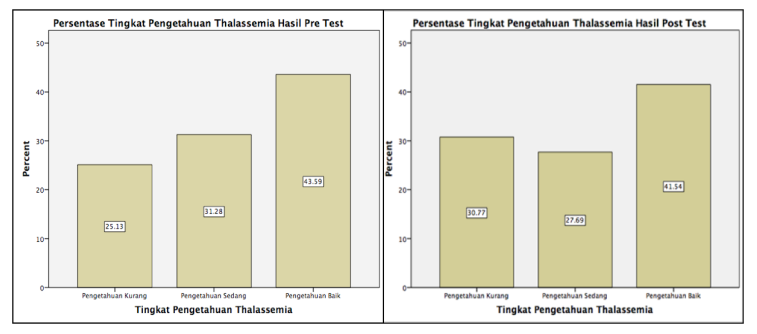

Gambar 1. Tingkat Pengetahuan Thalassemia Sebelum dan Sesudah Diberikan Edukasi

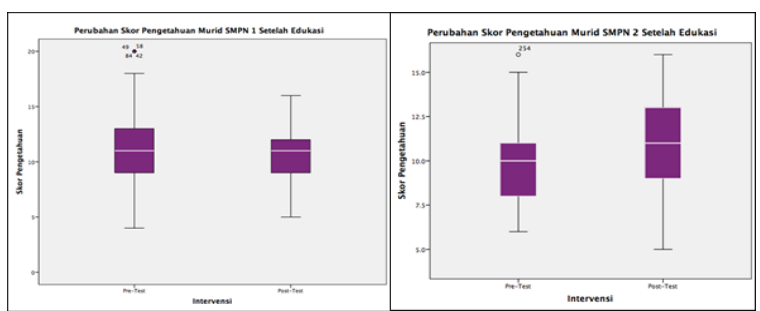

Gambar 2. Perubahan Skor Pengetahuan Thalassemia Setelah Diberikan Edukasi Berdasarkan Lokasi SMP
Pada tabel 2 menunjukkan pola distribusi data dari hasil pre test, post test responden penelitian berdasarkan lokasi sekolah. Pada pre test responden baik SMP 1 dan SMP 2 diperoleh nilai minimum dan maksimum berturut-turut adalah 4 dan 6 . Kemudian setelah dilakukan intervensi lalu dilakukan post test, didapatkan hasil yang signifikan dimana pada skor post test terdapat peningkatan rata-rata sebanyak 1,09 pada siswa/siswi SMP 2. Namun, hal ini tidak terjadi pada siswa/siswi SMP 1 dengan nilai minimum dan maksimum berturut-turut menjadi 4 dan 5 , hasil tidak signifikan terdapat perubahan pengetahuan ( $>00,05)$.

Penelitian mengenai skrining pembawa sifat kepada populasi yang beresiko merupakan sebuah langkah awal untuk mengembangkan sebuah program skrining yang cost-effective untuk kelainan genetik yang diwariskan secara autosomal resesif di negara berkembang, khususnya untuk penyakit thalassemia (Sarwani SR and Nurhayati 2014). Masyarakat awam cenderung sedikit memiliki pengetahuan tentang thalassemia sehingga kewaspadaan yang lebih rendah terhadap diri dan keluarganya menjadi menyebabkan sulitnya melakukan autoscreening. Berdasarkan penelitian yang telah dilakukan, hasilnya menunjukkan bahwa pengetahuan thalassemia merupakan salah satu hal penting yang harus dipahami oleh masyarakat terutama yang berada di usia reproduktif karena berkaitan dengan angka kejadian thalassemia setiap tahun yang masih terus merangkak naik. Program - program kesehatan oleh tenaga kesehatan di sekolah kepada siswa-siswinya dan penyampaian informasi yang tepat oleh petugas promosi kesehatan dinas kabupaten berperan penting dalam meningkatkan pengetahuan siswa untuk menghindari pernikahan antar sesama pembawa sifat thalassemia, sehingga jumlah penyandang thalassemia tidak semakin banyak (Rujito, Lestari et al. 2018)

Penelitian ini metode edukasi berupa penyuluhan dan efektifitas edukasi diukur dengan kuesioner. Setelah diimplementasikan, diperoleh hasil yang signifikan $(\mathrm{p}<$ 0.05) pada siswa/siswi SMP 2 Tempuran dimana terjadi peningkatan rata-rata skor pengetahuan antara sebelum dan setelah dilakukan intervensi. Beberapa faktor lain yang mempengaruhi pengetahuan yang dimiliki oleh anak yaitu tingkat pendidikan orangtuan namun pada penelitian ini tidak digali lebih dalam. Studi lain menun-jukkan bahwa edukasi yang diperoleh seorang anak sangat bergantung pada edukasi yang diperoleh

Tabel 2. Perubahan Skor Pengetahuan Thalassemia Setelah Diberikan Edukasi Berdasarkan Lokasi SMP

\begin{tabular}{|c|c|c|c|c|c|c|c|c|c|}
\hline \multirow{2}{*}{$\begin{array}{c}\text { Intervensi } \\
\text { Edukasi }\end{array}$} & \multicolumn{3}{|c|}{ SMPN 1} & \multicolumn{3}{|c|}{ SMPN 2} & \multirow[b]{2}{*}{ Post-test } & \multirow[b]{2}{*}{$\mathrm{t}$} & \multirow[b]{2}{*}{$\mathrm{p}$ value } \\
\hline & Pre-Test & & test & $\mathrm{t}$ & $\mathrm{p}$ value & Pre-Test & & & \\
\hline Rata-rata & 10,98 & 10,63 & 0,913 & & 0,364 & 9,91 & 11 & $-3,861$ & $<0,001$ \\
\hline $\begin{array}{l}\text { Simpangan } \\
\text { Baku }\end{array}$ & 3,432 & 2,211 & & & $\begin{array}{l}2,176 \\
6\end{array}$ & 2,334 & & & \\
\hline Min & 4 & 5 & & & 16 & 5 & & & \\
\hline Maks & 20 & 16 & & & & 16 & & & \\
\hline
\end{tabular}


orangtua mereka sewaktu kecil. Dikatakan bahwa orangtua dengan tingkat pendidikan yang tinggi cenderung memiliki kemampuan interaksi yang lebih baik dengan anak mereka dibandingkan orangtua yang berpendidikan rendah karena mereka cenderung lebih memikirkan kehidupan sehari-hari mereka yang kurang mencukupi dan hal ini mempengaruhi kemampuan serta kesempatan mereka untuk berinteraksi dengan anak mereka yang pada akhirnya juga mempengaruhi pengetahuan yang dimiliki seorang anak (Gratz, Nation et al. 2006).

Selain tingkat pendidikan, latar belakang ekonomi orangtua pun mempengaruhi pengetahuan seorang anak, dan pada penelitian ini informasi tersebut tidak ditanyakan. Namun, secara umum tingkat perekonomian di wilayah Kecamatan Tempuran, Kabupaten Kerawang berada pada tingkat menengah ke bawah dengan mata pencaharian terbanyak adalah bertani dan berdagang. Orangtua dengan pendapatan yang cenderung rendah biasanya akan bekerja lebih lama untuk mendapatkan pendapatan yang tidak seberapa itu. Waktu yang mereka gunakan untuk bekerja itu dapat mengurangi keterlibatan orangtua untuk mendampingi anak belajar. Biasanya juga akan ada konflik yang terjadi di rumah karena adanya tekanan akibat stress di dalam keluarga yang berpengaruh pada perfoma akademik anak di sekolah. Namun tidak selalu bahwa orangtua dengan latar belakang ekonomi yang rendah akan menjadi seperti itu, tetapi hampir sebagian besar kondisi yang mereka alami akan mengarah ke dalam stereotipe tersebut (Ncho and Wright 2013). Studi ini sesuai dengan penelitian yang dilakukan dimana lebih dari setengah subjek penelitian menyatakan bahwa pendapatan orangtua mereka per bulan kurang dari 2,6 juta yaitu batas bawah yang ditetapkan oleh bank dunia. Hal ini dapat mempengaruhi fasilitas belajar anak yang seharusnya dimiliki dengan baik sebagai sarana pendukung belajar seorang anak (Organization 2015).

Adapun keterbatasan pada penelitian ini adalah saat pengisian pre test dan post test yaitu kondisi sekolah yang kurang kondusif terutama di SMP 1, karena banyak siswasiswi lain di luar ruang kelas dan ada beberapa siswa yang tetap bekerja sama dalam pengisian kuesioner meskipun sudah diperingatkan berkali-kali.

\section{SIMPULAN}

Penelitian ini menunjukkan bahwa edukasi berupa penyuluhan merupakan sarana program pendidikan kesehatan dapat meningkatkan pengetahuan dari siswa Sekolah Menengah Pertama (SMP). Intervensi menggunakan media lain yang mengedepankan audio visual dapat dijadikan sebagai bahan pertimbangan dalam menyampaikan informasi kesehatan dalam hal ini pencegahan thalassemia. Hasil dari penelitian ini diharapkan dapat membantu Dinas Kesehatan Kabupaten Kerawang dalam melaksanakan program konseling kesehatan kepada masyarakat sebagai sarana preventif dan promotif. Selain itu, dapat dijadikan pertimbangan untuk pihak terkait seperti sekolah agar memanfaatkan materi edukasi thalassemia dengan pembelajaran yang lebih menarik dan efektif agar meningkatnya cakupan autoscreening pada populasi dengan usia produktif.

\section{DAFTAR PUSTAKA}

Cao, A. and Y. W. Kan (2013). "The prevention of thalassemia." Cold Spring Harbor perspectives in medicine 3(2): a011775.

Cousens, N. E., C. L. Gaff, S. A. Metcalfe and M. B. Delatycki (2010). "Carrier screening for betathalassaemia: a review of international practice." European journal of human genetics 18(10): 1077.

Dewi, S. (2009). "Karakteristik Thalasemia yang Dirawat Inap di Rumah Sakit Umum Pusat H. Adam Malik Medan.” Jurnal Skripsi. USU Repository: 10-12.

Gratz, J., S. O. Nation, S. O. Schools and R. Kurth-Schai (2006). "The Impact of Parents' Background on their Children's Education."

Modell, B. and M. Darlison (2008). “Global epidemiology of haemoglobin disorders and derived service indicators." Bulletin of the World Health Organization 86: 480-487.

Ncho, C. D. and S. C. J. c. Wright (2013). "Health maintenance and low socio-economic status: A family perspective." 36(1): 1-7.

Organization, W. H. (2015). Global status report on road safety 2015, World Health Organization.

Pour, M. N., M. F. Hagh, A. A. M. Akbari, A. A. H. P. Feyzi and M. Malaki (2015). "Genetic Variation Impacts in Patients with Major Beta-Thalassemia.” Iranian journal of public health 44(5): 722-723.

Rakhmilla, L. E., R. Larasati, E. K. Sahiratmadja, E. Rohmawaty, S. Susanah and S. H. Effendi (2018). "Assessing Knowledge About Thalassemia Among Reproductive Age Population After Video Media Education." Journal of Biomedical and Clinical Sciences (JBCS) 2(2): 30-32.

Rujito, L., D. W. D. Lestari, A. Aziz and D. Faiza (2018). "Sosialisasi Thalassemia Kepada Guru Biologi di Banyumas: Upaya Pencegahan Terintegrasi Melalui Kurikulum Sekolah.” Jurnal Pengabdian Pada Masyarakat 3(1): 1-6.

Sarwani SR, D. and N. Nurhayati (2014). "Efektifitas Ceramah terhadap Pengetahuan Kader Kesehatan tentang Penyakit Talasemia di Kecamatan Pekuncen dan Kecamatan Sumbang Kabupaten Banyumas.” Kes Mas: Jurnal Fakultas Kesehatan Masyarakat 8(1). 